\title{
$17 \beta$-Estradiol Primes Elicitation of Inducible Nitric Oxide Synthase Expression by Lipopolysaccharide and Interferon- $\gamma$ in Mouse Macrophage Cell Line J774.1
}

\author{
Humitoshi Sakazaki, Ryoko Ido, Hitoshi Ueno, and Katsuhiko Nakamuro* \\ Division of Environmental Health, Faculty of Pharmaceutical Sciences, Setsunan University, 45-1 Nagaotoge-cho, Hirakata, Osaka \\ 573-0101, Japan
}

(Received October 12, 2004; Accepted November 9, 2004; Published online November 11, 2004)

\begin{abstract}
The effects of estrogenic compounds on nitric oxide (NO) production by macrophages were examined. $17 \beta$ Estradiol promoted NO production triggered by lipopolysaccharide (LPS) and/or interferon (IFN)- $\gamma$ in the mouse macrophage cell line J774.1. Other estrogen-like substances such as estrone, $17 \alpha$-ethynylestradiol and bisphenol A also enhanced NO synthesis, but this NO synthesis was not activated by $\mathrm{Ca}^{2+}$ ionophore A23187. RT-PCR analysis demonstrated induction of inducible nitric oxide synthase (iNOS) mRNA in J774.1 cells exposed to 17 $\beta$-estradiol. Although the estrogen receptor (ER)-antagonist ICI-182780 partially suppressed the promoting effect of $17 \beta$-estradiol on NOS activity, there was little ER $\alpha$ detectable by RT-PCR from J774.1 cells. These results suggest that ERs may participate only partially in iNOS mRNA transcription in J774.1 cells and that $17 \beta$-estradiol may act directly through other unknown intracellular signal transduction(s) that are activated by LPS and IFN- $\gamma$.
\end{abstract}

Key words — $17 \beta$-estradiol, macrophage, nitric oxide, endocrine disrupting chemical

\section{INTRODUCTION}

Endocrine hormones play important roles in cell differentiation, growth and the reproductive functions of humans and animals. The endocrine system, immune system and nervous system affect each other, and these three systems organize higher regulation systems to maintain homeostasis in the body. ${ }^{1)}$ The female hormone estrogen is involved not only with female phenotypes but also has both beneficial and adverse effects on human health. ${ }^{2,3)}$ For example, estrogens are used postmenopausally for treatment of osteoporosis ${ }^{4)}$ or vasomotor neuropathy. ${ }^{5)}$ However, estrogen has been incriminated in the onset of cardiovascular diseases, ${ }^{6}$ apoplexy, ${ }^{7)}$ various neurodegenerative diseases including Alzheimertype dementia, ${ }^{8)}$ and promotion of carcinogenesis in the breast ${ }^{9)}$ and endometrium. ${ }^{10)}$ Moreover, estrogen increases the risk of developing autoimmune dis-

\footnotetext{
*To whom correspondence should be addressed: Division of Environmental Health, Faculty of Pharmaceutical Sciences, Setsunan University, 45-1 Nagaotoge-cho, Hirakata, Osaka 5730101, Japan. Tel.: +81-72-866-3122; Fax: +81-72-866-3123; Email: nakamuro@pharm.setsunan.ac.jp
}

eases such as systemic lupus erythematosus (SLE) and rheumatoid arthritis. ${ }^{11,12)}$ Additionally, it is reported that chemicals discharged into the environment may cause abnormalities in human reproduction and wildlife breeding. These environmental pollutants are called endocrine disrupting chemicals (EDCs), and some of them show estrogen-like actions in biological systems. ${ }^{13)}$ These EDCs may also exert the adverse actions of endogenous estrogen.

In immune responses, immunocompetent cells infiltrate affected areas to destroy xenobiotics or execute phagocytosis of them. This infiltration of cells and the humoral factors released cause inflammation characterized by pain, fever, flaring and swelling. These symptoms often disturb the normal functions of inflamed tissues. A continuous inflammation may result in an ulcer and sometimes necrosis of the tissue. Thus, the immune response has both useful effects and detrimental actions. This inconsistency is partially due to nitric oxide (NO). NO, as well as super oxide anion, is produced mainly by macrophages during the immune response and damages tumors or microorganisms. ${ }^{14)}$ NO promotes inflammation and immune responses, controls proliferation of $\mathrm{T}$ cells by stopping the cell cycle progres- 
sion in the $\mathrm{G} 1 / \mathrm{S}$ phase ${ }^{15)}$ and suppresses the degranulation of mast cells. ${ }^{16)}$ On the other hand, a highlevel of NO can injure normal tissues. In one of the autoimmune diseases, type I diabetes, the activated macrophage-secreted NO injures $\beta$ cells of the islets of Langerhans in the pancreas. ${ }^{17)} \mathrm{NO}$ production rises in the inflamed regions of patients suffering from autoimmune diseases and causes various injuries in organs and tissues. ${ }^{18)}$

NO is produced by the enzymatic oxidation of $\mathrm{L}$-arginine. There are three isozymes of nitric oxide synthase (NOS) ${ }^{19)}$ endothelial NOS (eNOS), neuronal NOS (nNOS) and inducible NOS (iNOS), which are distributed primarily in vascular endothelium, nerve cells and macrophages, respectively. Of these isoforms, eNOS and nNOS are constitutively located on the cell membrane, and also called constitutive NOS (cNOS). Inducible NOS is distributed to macrophages and other leukocytes, and production is transiently stimulated by cytokines and lipopolysaccharides. It is generally known that production of NO by eNOS in vascular endothelial cells differs between the sexes, and much more tends to be produced in females than males..$^{20,21)}$ Therefore, $17 \beta$-estradiol may change eNOS into the active form by activating some intracellular kinase cascade. This activation may be triggered by an estrogen receptor $(\mathrm{ER})$, which is one of the intranuclear receptors. Finally, NO promoted by $17 \beta$-estradiol prevents arteriosclerosis through repression of platelet agglutination and lymphocyte adhesion. It is also reported that $17 \beta$-estradiol promotes the transcription of eNOS mRNA through binding to ERs in vascular endothelial cells. ${ }^{22,23)}$ An ER was also found in mouse spleen lymphocytes. ${ }^{24)}$ These data suggest that $17 \beta$ estradiol promotes transcription of iNOS mRNA through binding to an ER in lymphocytes to increase NO in the immune cells. However, little evidence that estrogen induces NO synthesis in the immune system has been shown.

In this research, the relevance of the actions of estrogens to NO synthesis in the mouse macrophage cell line $\mathrm{J} 774.1^{25}$ ) was examined using the diaminofluorescein-2 (DAF-2) fluorescence method. ${ }^{26)}$ The effects of EDCs on the production of NO were also examined using J774.1 cells, and the class of NOS producing NO in these cells and the involvement of ERs were determined.

\section{MATERIALS AND METHODS}

Reagents — $17 \beta$-Estradiol was purchased from Wako Pure Chemical Industries, Ltd. (Osaka, Japan). Lipopolysaccharide, interferon (IFN)- $\gamma$, concanavalin A, L-arginine, and phenol-red-free RPMI-1640 medium were obtained from Sigma-Aldrich Inc. (St. Louis, MO, U.S.A.). DAF-2 and DAF-2T were purchased from Daiichi Pure Chemicals Co., Ltd. (Tokyo, Japan). The ER antagonist ICI-182780 was a generously provided by AstraZeneca (London, U.K.). A23187 was obtained from Merck KgaA (Darmstadt, Germany). J774.1 cells were purchased from Japanese Collection of Research Bioresources (Tokyo, Japan). All other reagents were of the highest grade commercially available.

Cell Culture — J774.1 cells were cultured in RPMI-1640 medium under $5 \% \mathrm{CO}_{2}$ at $37^{\circ} \mathrm{C}$. The RPMI-1640 medium was supplemented by $5 \mathrm{mM}$ $N$-2-hydroxyethylpiperazine- $N^{\prime}$-2-ethanesulfonic acid (HEPES), $50 \mu \mathrm{M}$ 2-mercaptoethanol, $50 \mathrm{mg} / \mathrm{l}$ potassium benzyl penicillin, $50 \mathrm{mg} / \mathrm{l}$ streptomycin sulfate, $0.18 \% \mathrm{NaHCO}_{3}$ and $10 \%$ fetal calf serum. Cells, $1 \times 10^{5}$, were put into each well of 48 -well microplates with $500 \mu \mathrm{l}$ of medium. $17 \beta$-Estradiol was added at the final concentration of $10^{-8} \mathrm{~mol} / \mathrm{l}$, and cells were incubated for $24 \mathrm{hr}$. Cells were washed with Krebs-Ringer buffer and cultured for a further $24 \mathrm{hr}$ in new medium containing $10 \mathrm{mg} / \mathrm{l} \mathrm{li}$ popolysaccharide (LPS) ${ }^{27)}$ and/or $0.2 \mu \mathrm{g} / \mathrm{l} \mathrm{IFN}-\gamma^{28}$ ) $\mathrm{A} \mathrm{Ca}^{2+}$ ionophore, $\mathrm{A} 23187,{ }^{29)}$ was added at the concentration of $2 \mathrm{mg} / \mathrm{l}$ to $2 \times 10^{5}$ cells in each well and incubated for $30 \mathrm{~min}$. The final concentration of dimethyl sulfoxide (DMSO), the vehicle of $17 \beta$-estradiol and A23187, was limited to $0.1 \%$.

Determination of NO — The DAF-2 fluorescence method was performed according to a previous report. ${ }^{26)}$ The cultured cells were washed once with Krebs-Ringer buffer and incubated in $300 \mu \mathrm{l}$ of the new buffer containing $100 \mu \mathrm{mol} / \mathrm{l}$ of L-arginine and $1 \mu \mathrm{mol} / \mathrm{l}$ of DAF- 2 for $2 \mathrm{hr}$ at $37^{\circ} \mathrm{C}$. After incubation, $200 \mu \mathrm{l}$ of the supernatant was transferred to a black 96-well microplate (Thermo Labsystems Oy., Helsinki, Finland), and the fluorescence of DAF-2T was measured at wavelengths of $490 \mathrm{~nm}$ for excitation and $520 \mathrm{~nm}$ for emission with an MTP-600F microplate reader (Corona Electric Co., Ltd., Ibaraki, Japan). The amount of extracellular NO was determined by a calibration curve using authentic DAF$2 \mathrm{~T}$. The total cellular amount was determined by the ethidium bromide fluorescence method. ${ }^{30,31)}$ Briefly, the cells were washed once with $200 \mu$ of PBS, 
$200 \mu \mathrm{l}$ of $0.1 \%$ sodium dodecyl sulfate (SDS) was added, and they were left for $30 \mathrm{~min}$ to lyse. Then, $100 \mu \mathrm{l}$ of $50 \mu \mathrm{g} / \mathrm{ml}$ ethidium bromide was added to each well, they were incubated for $15 \mathrm{~min}$, and the complex formed by DNA and ethidium bromide was determined fluorometrically with emission at $620 \mathrm{~nm}$ and excitation at $515 \mathrm{~nm}$ with a microplate reader (MTP-200F, Corona Electric Co., Ltd.) as an indication of cell number. A calibration curve for cell was obtained to calculate the number of cells in a well.

RT-PCR of iNOS mRNA — Ribonuclease (RNase)-free plastic and water were used throughout the assay. J774.1 cells were suspended in the phenol-red-free RPMI-1640 medium. Cells were homogenized in $1 \mathrm{ml}$ of Sepazol (Nacalai Tesque, Inc., Kyoto, Japan) and underwent acid guanidium thiocyanate-phenol-chloroform extraction according to the manufacturer's protocol. Five micrograms of total RNA were allowed for reverse transcription using the Superscript II Preamplification System (GibcoBRL Invitrogen Co., Carlsbad, CA, U.S.A.). All reactions were performed in a thermal cycler (Takara Bio Inc., Shiga, Japan). One $\mu \mathrm{l}$ of $100 \mu \mathrm{M}$ iNOS primers $\left(5^{\prime}{ }_{198}\right.$ GTCAACTGCAAGAGAACG GAGAAC $_{223} 3^{\prime}, 5^{\prime}{ }_{634}$ GAGCTCCTCCAGAGGGGT $\mathrm{AGG}_{654} 3^{\prime}$ ) was used to amplify iNOS. ${ }^{32)}$ The oligonucleotides used to amplify glyceraldehyde-3-phosphate dehydrogenase (G3PDH) mRNA were purchased from Clontech Laboratories, Inc. (Palo Alto, CA, U.S.A.). The primers for amplification of $\mathrm{ER} \alpha$ were previously reported. ${ }^{33)}$

Statistical Analysis — The data represent mean \pm standard deviation of measurements obtained from triplicate samples. Statistical comparison between groups was performed using Student's $t$-test. Statistical significance was set at $p<0.05$.

\section{RESULTS}

\section{7 $\beta$-Estradiol Augments NO-Synthesis Elicited by LPS and IFN- $\gamma$}

As shown in Fig. 1, the production of NO was detected from cells with LPS stimulation and from cells with IFN- $\gamma$ stimulation, and greater production was detected from cells costimulated with LPS and IFN- $\gamma .17 \beta$-Estradiol itself did not induce NO. However, NO production was increased by pre-exposure to $10^{-8} \mathrm{~mol} / \mathrm{l} 17 \beta$-estradiol in case of LPS stimulation, IFN- $\gamma$ stimulation or costimulation of LPS and IFN- $\gamma$.

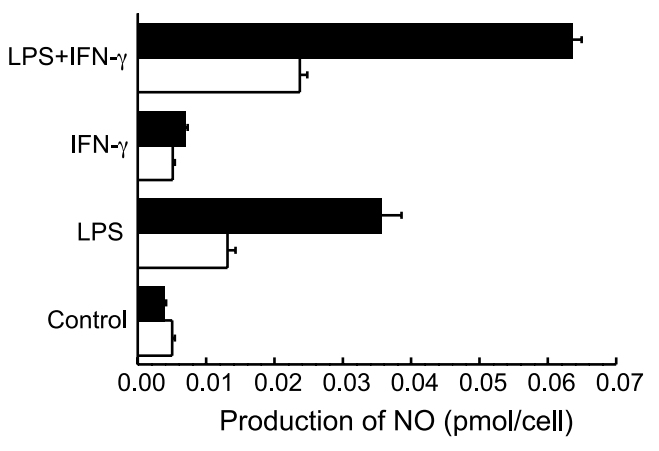

Fig. 1. Effect of $17 \beta$-Estradiol on amount of NO Per Surviving Cell Produced by J774.1 after Induction by LPS and/or IFN- $\gamma$

$\mathrm{J} 774.1$ were exposed to $10^{-8} \mathrm{~mol} / 1$ of $17 \beta$-estradiol (closed bar) or not (open bar) for $24 \mathrm{hr}$, washed and treated with $10 \mathrm{mg} / \mathrm{l} \mathrm{LPS}$ and/or $0.2 \mathrm{mg} / \mathrm{l} \mathrm{IFN}-\gamma$ for $24 \mathrm{hr}$. Then, NO synthase activity was measured. In addition, the number of $\mathbf{J} 774.1$ cells cultured under this condition was assayed by the ethidium bromide fluorescent method.

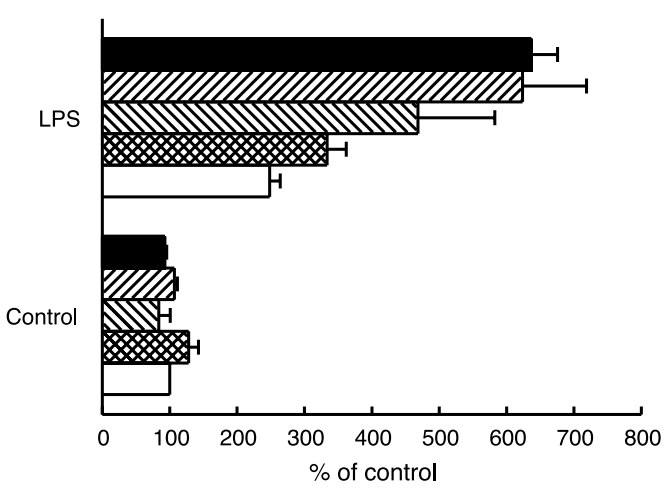

Fig. 2. Effect of Estrone, $17 \alpha$-Ethynylestradiol and Bisphenol A on NO Production of $\mathbf{J} 774.1$

J774.1 were exposed to test compounds and incubated with or

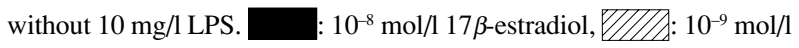
estrone, MW: $10^{-6} \mathrm{~mol} / 1 \quad 17 \alpha$-ethynylestradiol, $10^{-5} \mathrm{~mol} / 1$ bisphenol A, $\square$ : none.

Bisphenol A, $17 \alpha$-ethynylestradiol and estrone were also tested for their ability to increase NO production in J774.1 cells with LPS stimulation (Fig. 2). Concentrations of these chemicals were determined by the ratio of affinities to ER $\alpha$ estimated by a yeast two-hybrid assay ${ }^{34)}$ so that each EDC exerted sufficient activity. None of them promoted NO production by themselves. However, all three chemicals enhanced the stimulating effect of LPS, which indicates that environmental EDCs also prime NO synthesis in macrophages. Of these substances, $17 \beta$-estradiol had the strongest effect on NO production in macrophages, and bisphenol A had a weaker effect than had been expected from its concentration and 


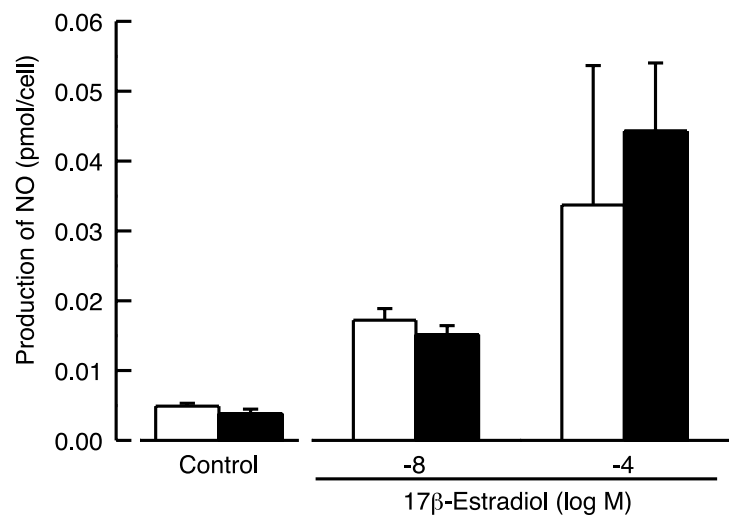

Fig. 3. Effect of A23187 on NO Production of J774.1

J774.1 cells were exposed to $17 \beta$-estradiol for $24 \mathrm{hr}$, washed to remove $17 \beta$-estradiol from the medium, incubated with (closed bar) or without (open bar) $\mathrm{Ca}^{2+}$ ionophore A23187 for $30 \mathrm{~min}$, and $\mathrm{NO}$ production was assayed.

its affinity to $\mathrm{ER} \alpha$.

\section{Enhancement of 17 $\beta$-Estradiol on Expression of iNOS mRNA}

To identify the subtype of NOS, the $\mathrm{Ca}^{2+}$ dependency of NOS was investigated with the $\mathrm{Ca}^{2+}$ ionophore A23187 (Fig. 3). The NO productions tended to be enhanced by $10^{-4} \mathrm{~mol} / \mathrm{l}$, probably toxic concentration, of $17 \beta$-estradiol. Despite the presence of A23187 treatment, no enhancement in NOS activity was observed. These results suggest that $17 \beta$-estradiol promoted production of $\mathrm{Ca}^{2+}$-independent iNOS.

The transcription of iNOS mRNA in J774.1 cells exposed to $17 \beta$-estradiol was examined by RT-PCR (Fig. 4). The results showed that iNOS mRNA was induced by LPS and IFN- $\gamma$ stimulation and that iNOS mRNA was not detected with only $17 \beta$-estradiol. However, when $17 \beta$-estradiol was added prior to LPS and/or IFN- $\gamma$, the quantity of iNOS mRNA was increased. These results indicate that $17 \beta$-estradiol promoted NO production by increasing iNOS mRNA.

\section{Involvement of ER in NO Production}

To examine the involvement of ERs in iNOS expression in J774.1 cells, the effect of an ER antagonist, ICI-182780, on $17 \beta$-estradiol-enhanced NO production was investigated (Fig. 5). ICI-182780 slightly inhibited the priming effect of $17 \beta$-estradiol on the NO production in J774.1 cells. However, the addition of a 10-times higher concentration of ICI182780 to that of $17 \beta$-estradiol did not completely
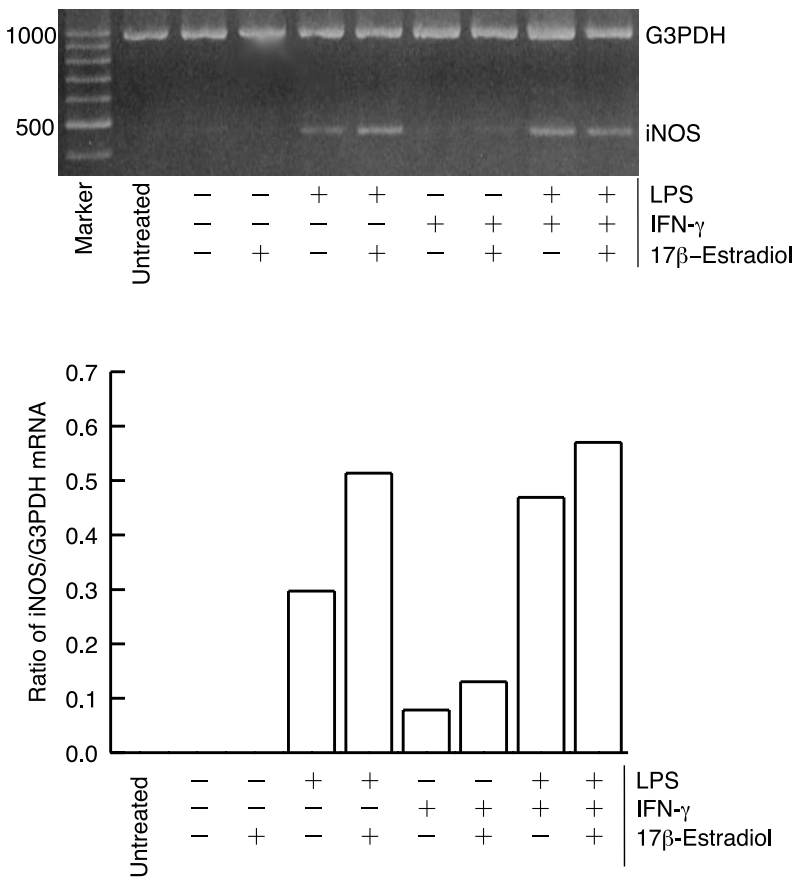

Fig. 4. Effect of $17 \beta$-Estradiol on Expression of iNOS mRNA in J774.1 Stimulated by LPS and/or IFN- $\gamma$

J774. 1 cells were exposed to $10^{-8} \mathrm{~mol} / 1$ of $17 \beta$-estradiol for $24 \mathrm{hr}$, washed to remove $17 \beta$-estradiol in the nutrient medium and stimulated by LPS and/or IFN- $\gamma$ for $24 \mathrm{hr}$. After that, the iNOS mRNA quantity was measured with an RT-PCR method (A). The electrophoretic bands were quantified and normalized to the amount of G3PDH mRNA (B).

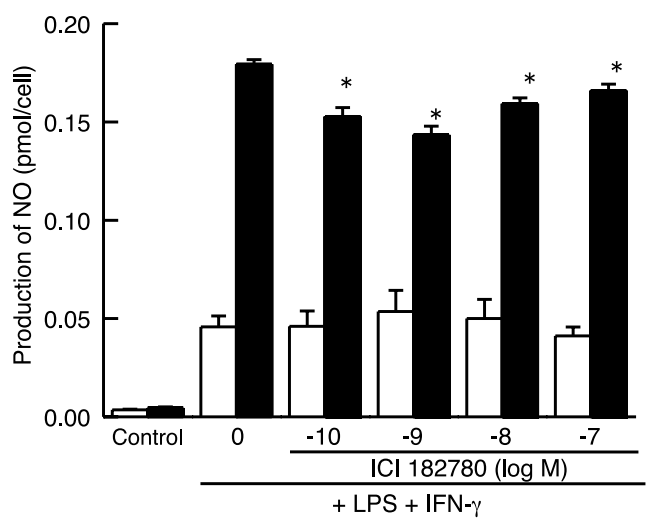

Fig. 5. Effect of Estrogen Receptor Antagonist ICI-182780 on $17 \beta$-Estradiol Enhancement of NOS Activity in J774.1 Stimulated by LPS and IFN- $\gamma$

J774. 1 cells were exposed to $10^{-10}-10^{-7} \mathrm{~mol} / \mathrm{l}$ of ICI- 182780 and $10^{-8} \mathrm{~mol} / \mathrm{l} 17 \beta$-estradiol for $24 \mathrm{hr}$, stimulated for $24 \mathrm{hr}$ by LPS and IFN$\gamma$, and NO production was measured. Open bars represent NOS activity of cells not exposed to $17 \beta$-estradiol and closed bars represent those exposed E2. *Statistically different from the control without ICI-182780 $(p<0.05)$.

inhibit the NO production. Because the ER antagonist only partially inhibited the priming effect of $17 \beta$ estradiol on NO synthesis, the existence of $\mathrm{ER} \alpha$ in 


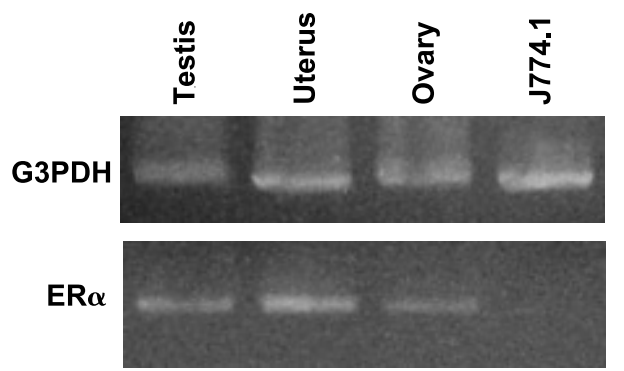

Fig. 6. Expression of mRNA of ER $\alpha$ in J774.1 and Testis, Uterus and Ovary of BALB/c Mice

Total RNA was extracted from J774.1 cells and each organ as positive controls, and mRNA of ER $\alpha$ was detected.

J774.1 cells was examined by the RT-PCR method. No ER $\alpha$ mRNA was detected in J774.1 cells, although ER $\alpha$ mRNA was observed in the testis, ovary and uterus of 5-week-old BALB/c mice used as positive controls (Fig. 6). These results suggest that $17 \beta-$ estradiol enhanced the transcription of iNOS mRNA in J774.1 cells through a mechanism other than ER $\alpha$.

\section{DISSCUSSION}

The fact that autoimmune diseases such as SLE and rheumatoid arthritis tend to occur mainly in women generally suggests that estrogens affect the immune system. Induction of NO has been observed in inflamed tissues of patients suffering from these diseases and is suggested to be related to harmful actions of the immune system. $17 \beta$-Estradiol is well known to enhance NO production in vascular endothelial cells and nerve cells. On the other hand, it is still unclear whether $17 \beta$-estradiol enhances NO production in immune cells. Therefore the influence of $17 \beta$-estradiol on NO production in macrophages, which are reported to produce $\mathrm{NO},{ }^{25}$ ) was investigated.

The mouse macrophage cell line J774.1 produced NO after stimulation by LPS derived from Escherichia coli or IFN- $\gamma$. Further, the cells pre-exposed to $17 \beta$-estradiol produced more NO after they were stimulated with LPS and IFN- $\gamma$ (Fig. 1), although $17 \beta$-estradiol itself failed to induce NO. These results suggest that $17 \beta$-estradiol primes NO production and augments the activities of macrophages when they attack bacteria or are stimulated by type-1 helper T cells.

Because $17 \beta$-estradiol promoted NO synthesis in macrophages stimulated by LPS and IFN- $\gamma$, we examined whether EDCs, which bind to ERs and act like estrogens, also increase the NO production in J774.1 cells with LPS stimulation. The EDCs tested were bisphenol A, a typical EDC used as a plasticizer of synthetic resin, $17 \alpha$-ethynylestradiol, an artificial estrogen used therapeutically, and estrone, a metabolite of $17 \beta$-estradiol. These chemicals were added to the cells in sufficient concentration to bind $\mathrm{ER} \alpha$. The results indicate that the priming effect of bisphenol A was relatively weaker than that of the others (Fig. 2). This finding suggests that EDCs may affect NO synthesis of macrophages in a manner other than by binding to ER $\alpha$.

$\mathrm{NO}$ is synthesized by an oxygenase domain and a reductase domain of NOS, which transfer an electron from an oxygen molecule to a guanidinoacetic group of an L-arginine molecule and release molecular NO. ${ }^{19)}$ NOS is classified into three types of isozymes, eNOS, nNOS and iNOS, found mainly in vascular endothelium, nerve cells and macrophages, respectively. Among those, eNOS and nNOS are located constitutively at or near the cell membrane and activated by binding to intracellular calcium ion, or activated through phosphorylation by a phosphatidylinositol-3-kinase (PI3K)-Akt pathway. ${ }^{35,36)}$ On the other hand, iNOS is not always present in cells and is induced transiently in immune cells and hepatocytes by cytokine or LPS stimulation; iNOS is located in the cytoplasm. Because $\mathrm{Ca}^{2+}$ binds iNOS constitutively, iNOS is not further activated by an influx of $\mathrm{Ca}^{2+}$ into cells. ${ }^{19)}$

Some reports showed that $17 \beta$-estradiol bound to ERs on the membrane of mouse $\mathrm{T}$ cells and elevated the intracellular concentration of $\mathrm{Ca}^{2+} .{ }^{37)}$ This influx of $\mathrm{Ca}^{2+}$ evoked by $17 \beta$-estradiol may activate eNOS or nNOS. However, the production of NO in J774.1 cells was not affected by the intracellular $\mathrm{Ca}^{2+}$ ionophore A23187 (Fig. 3). This suggests that $\mathrm{Ca}^{2+}$ is not involved in the action of $17 \beta$-estradiol on macrophages. The NOS may not be eNOS or nNOS, which possess $\mathrm{Ca}^{2+}$ dependency, but may be iNOS. In the stimulation by LPS and INF- $\gamma$, expression of iNOS mRNA was detected by RT-PCR and it was enhanced by $17 \beta$-estradiol (Fig. 4). This increment of iNOS mRNA was suggested to contribute to the increment of NO primed by $17 \beta$-estradiol.

It has been established that $17 \beta$-estradiol exerts its activity through the following mechanism: $17 \beta$ estradiol binds to an ER, two ERs form a dimer, the dimer binds to an estrogen response element (ERE) in DNA and the transcription of genes is activated. On the other hand, iNOS is regulated in the transcriptional step, and consequently, production of 
iNOS results in increased synthesis of NO. ${ }^{38)} \mathrm{ER} \alpha$ is expressed in vascular endothelium, and $17 \beta$-estradiol binds to $\mathrm{ER} \alpha$ to induce production of eNOS mRNA. ${ }^{22)}$ Because the expression of iNOS mRNA in $\mathrm{J} 774.1$ cells was promoted by $17 \beta$-estradiol (Fig. 4), it is suspected that $17 \beta$-estradiol bound to an ER in J774.1 and that the ER dimer subsequently bound to an ERE in the 5' side-flanking region of the iNOS gene. An ERE was searched for in the reported sequence of the $5^{\prime}$ side-flanking region of iNOS gene of mouse macrophages. ${ }^{39-41)}$ One consensus sequence to half of the ERE was found 1325 base pairs upstream from the transcription initiation point. It was possibly bound by a monomer of ER, although it is unclear at present whether the ER monomer really binds to this site and affects transcription. However, the full consensus sequence to ERE was not found, and ER dimers were suspected not to bind to this region.

A possibility that other mechanisms besides the transcriptional activation of ER as the mechanism of promoting iNOS expression of J774.1 cells with $17 \beta$-estradiol was suggested. Sequences besides ERE for binding with other transcriptional factors were searched for in the $5^{\prime}$-side flanking region of the iNOS gene. Possible binding sequences that can be activated by IFN- $\gamma$ or LPS were found, for example, IFN- $\gamma$ response element (IRE), $\gamma$-activated stimulated position (GAS), nuclear factor kappa B (NF- $\kappa \mathrm{B})$ and activating protein-1 (AP-1). It is reported that ERs can bind to AP-1 in human neuroblasts ${ }^{42}$ and human monocytes. ${ }^{43)}$ ERs in J774.1 could modify the transcriptional function of AP-1 instead of binding to the ERE sequence in DNA. LPS and IFN- $\gamma$ bind to Toll-like receptor 4 (TLR4) and interferon receptor (IFNR) on the cell membrane, respectively. Intracellular signal transduction pathways are activated, and finally, NF- $\kappa \mathrm{B}, \mathrm{AP}-1$ and binding factors to GAS, to induce the expression of the iNOS gene. ${ }^{44,45)}$ Our results suggest that ER $\alpha$ contributes little to iNOS mRNA transcription in J774.1 cells (Figs. 5 and 6). The observations above suggest that $17 \beta$-estradiol may participate directly at some point in intracellular signal transduction pathways.

Recently, a membrane-type receptor for progesterone was identified. ${ }^{46,47)}$ Progesterone binds to the receptor and suppresses guanylate cyclase activity. Estradiol was not shown to bind to this membranetype progesterone receptor, but another unknown receptor on the membrane might bind to $17 \beta$-estradiol and activate intracellular second messengers.

You et al. ${ }^{48)}$ and Tomaszewska et al. ${ }^{49)}$ have dem- onstrated that $17 \beta$-estradiol enhanced NO synthesis in mouse peritoneal macrophages and a mouse macrophage cell line, RAW264.7, respectively. Our results were consistent with their observations. It was demonstrated that $17 \beta$-estradiol induced iNOS mRNA in sufficient quantity to produce NO in the mouse macrophage cell line J774.1, but ER $\alpha$ hardly seemed to be involved in the priming activity of $17 \beta$ estradiol.

\section{REFERENCES}

1) Tomaszewska, D. and Przekop, F. (1997) The immune-neuro-endocrine interactions. J. Physiol. Pharmacol., 48, 139-158.

2) Bruce-Keller, A. J., Keeling, J. L., Keller, J. N., Huang, F. F., Camondola, S. and Mattson, M. P. (2000) Antiinflammatory effects of estrogen on microglial activation. Endocrinology, 141, 3646-3656.

3) Wise, P. M., Dubal, D. B., Wilson, M. E., Rau, S. W. and Bottner, M. (2001) Minireview: neuroprotective effects of estrogen - new insights into mechanisms of action. Endocrinology, 142, 969-973.

4) Termine, J. D. and Wong, M. (1998) Post-menopausal women and osteoporosis: available choices for maintenance of skeletal health. Maturitas, $\mathbf{3 0}$, 241-245.

5) Guzzo, J. A. (2000) Selective estrogen receptor modulators - a new age of estrogens in cardiovascular disease? Clin. Cardiol., 23, 15-17.

6) Roof, R. L. and Hal, E. D. (2000) Gender differences in acute CNS trauma and stroke: neuroprotective effects of estrogen and progesterone. $J$. Neurotrauma, 17, 367-388.

7) Henderson, V. W. (1997) Estrogen, cognition, and a woman's risk of Alzheimer's disease. Am. J. Med., 103, 11S-18S

8) Grodstein, F. and Stampfer, M. (1995) The epidemiology of coronary heart disease and estrogen replacement in postmenopausal women. Prog. Cardiovasc., 38, 199-210.

9) Colditz, G. A. (1998) Relationship between estrogen levels, use of hormone replacement therapy, and breast cancer. J. Natl. Cancer Inst., 90, 814-823.

10) Cohen, C. J. and Rahaman, J. (1995) Endometrial cancer. Management of high risk and recurrence including the tamoxifen controversy. Cancer, 76 (10 Suppl.), 2044-2052.

11) Castagnetta, L., Granata, O. M., Traina, A., Cocciadiferro, L., Saetta, A., Stefano, R., Cutolo, M. and Carruba, G. (2002) A role for sex steroids in autoimmune diseases: a working hypothesis and supporting data. Ann. N.Y. Acad. Sci., 966, 193-203. 
12) Cutolo, M., Sulli, A., Seriolo, B., Accardo, S. and Masi, A. T. (1995) Estrogens, the immune response and autoimmunity. Clin. Exp. Rheumatol., 13, 217226.

13) Menditto, A. and Turrio-Baldassarri, L. (1999) Environmental and biological monitoring of endocrine disrupting chemicals. Chemosphere, 39, 1301-1307.

14) Sorimachi, K., Akimoto, K., Hattori, Y., Leiri, T. and Niwa, A. (1999) Secretion of TNF- $\alpha$, IL-8 and nitric oxide by macrophages activated with polyanions, and involvement of interferon- $\gamma$ in the regulation of cytokine secretion. Cytokine, 11, 571-578.

15) van der Veen, R. C. (2001) Nitric oxide and T helper cell immunity. Int. Immunopharmacol., 1, 14911500.

16) Forsythe, P., Gilchrist, M., Kulka, M. and Befus, A. D. (2001) Mast cells and nitric oxide: control of production, mechanisms of response. Int. Immunopharmacol., 1, 1525-1541.

17) Kroncke, K. D., Kolb-Bachofen, V., Berschick, B., Burkart, V. and Kolb, H. (1991) Activated macrophages kill pancreatic syngeneric islet cells via arginine-dependent nitric oxide generation. Biochem. Biophys. Res. Commun., 175, 752-758.

18) Kroemer, G. and Martinez, C. (1991) Cytokines and autoimmune disease. Clin. Immunol. Immunopathol., 61, 275-295.

19) Tsutsui, M., Ueno, S., Toyohira, Y. and Yanagihara, N. (2002) Structure and function of nitric oxide synthases. Tanpakushitsu Kakusan Koso, 47, 20242031 (in Japanese).

20) Hayashi, T., Fukuto, J. M., Ignarro, L. J. and Chaudhuri, G. (1992) Basal release of nitric oxide from aortic rings is greater in female rabbits than in male rabbits: implications for atherosclerosis. Proc. Natl. Acad. Sci. U.S.A., 89, 11259-11263.

21) Hayashi, T., Fukuto, J. M., Ignarro, L. J. and Chaudhuri, G. (1995) Gender differences in atherosclerosis: possible role of nitric oxide. J. Cardiovasc. Pharmacol., 26, 792-802.

22) Hayashi, T., Yamada, K., Esaki, T., Kuzuya, M., Satake, S., Ishikawa, T., Hidaka, H. and Iguchi, A. (1995) Estrogen increases endothelial nitric oxide by a receptor-mediated system. Biochem. Biophys. Res. Commun., 214, 847-855.

23) Kim, H. P., Lee, J. Y., Jeong, J. K., Bae, S. W., Lee, H. K. and Jo, I. (1999) Nongenomic stimulation of nitric oxide release by estrogen is mediated by estrogen receptor $\alpha$ localized in caveolae. Biochem. Biophys. Res. Commun., 263, 257-262.

24) Sakazaki, H., Ueno, H. and Nakamuro, K. (2002) Estrogen receptor $\alpha$ in mouse splenic lymphocytes: possible involvement in immunity. Toxicol. Lett., 133, 221-229.
25) Marcinkiewicz, J., Pater, M. and Grabowska, A. (1994) An improved experimental model for the study of in vitro release of nitric oxide by murine peritoneal macrophages. Arch. Immunol. Ther. Exp. (Warsz), 42, 95-99.

26) Jurgen, F. L., Thomas, R. R., Christian, M., Angelika, M. V. and Verena, M. D. (2001) Reliable in vitro measurement of nitric oxide released from endothelial cells using low concentrations of fluorescent probe 4,5-diaminofluorescein. FEBS Lett., 506, 131134.

27) Misko, T. P., Schilling, R. J., Salvemini, D., Moore, W. M. and Currie, M. G. (1993) A fluorometric assay for the measurement of nitrite in biological samples. Anal. Biochem., 214, 11-16.

28) Chan, E. D. and Riches, D. W. (2001) IFN- $\gamma+$ LPS induction of iNOS is modulated by ERK, JNK/ SAPK, and p38 (mapk) in a mouse macrophage cell line. Am. J. Physiol. Cell Physiol., 280, C441-C450.

29) Brooks, B., Robinson, J. H. and Windebank, K. P. (1995) Flow cytometric determination of intracellular calcium changes in human peripheral blood mononuclear cells during conjugation to tumour cell lines. J. Immunol. Methods, 178, 229-239.

30) Itoh, Y., Fukamachi, I., Nakajima, K., Kawai, T. and Nakao, K. (1983) A new method for the evaluation of lymphocyte activation by ethidium bromide fluorescence assays. Journal of Clinical and Experimental Medicine, 126, 21-22 (in Japanese).

31) Sakazaki, H., Ueno, H. and Nakamuro, K. (2001) Immunotoxicological evaluation of environmental chemicals utilizing mouse lymphocyte mitogenesis test. J. Health Sci., 47, 258-271.

32) Han, B., DuBois, D. C., Boje, K. M., Free, S. J. and Ahnon, R. R. (1999) Quantification of iNOS mRNA with reverse transcription polymerase chain reaction directly from cell lysates. Nitric Oxide, 3, 281291.

33) White, R., Lees, J. A., Needham, M., Ham, J. and Parker, M. (1987) Structural organization and expression of the mouse estrogen receptor. Mol. Endocrinol., 1, 735-744.

34) Nishihara, T., Nishikawa, J., Kanayama, T., Dakeyama, F., Saito, K., Imagawa, M., Takatori, S., Kitagawa, Y., Hori, S. and Utsumi, H. (2000) Estrogenic activities of 517 chemicals by yeast two-hybrid assay. J. Health Sci., 46, 282-298.

35) Fulton, D., Gratton, J. P., McCabe, T. J., Fontana, J., Fujio, Y., Walsh, K., Franke, T. F., Papapetropoulos, A. and Sessa, W. C. (1999) Regulation of endothelium-derived nitric oxide production by the protein kinase Akt. Nature (London), 399, 597-601.

36) Dimmeler, S., Fleming, I., Fisslthaler, B., Hermann, C., Busse, R. and Zeiher, A. M. (1999) Activation 
of nitric oxide synthase in endothelial cells by Aktdependent phosphorylation. Nature (London), 399, 601-605.

37) Benten, W. P. M., Lieberherr, M., Giese, G. and Wunderlich, F. (1998) Estradiol binding to cell surface raises cytosolic free calcium in T cells. FEBS Lett., 422, 349-353.

38) Stuehr, D. J. and Marlette, M. A. (1987) Induction of nitrite/nitrate synthesis in murine macrophages by BCG infection, lymphokines or interferon- $\gamma . J$. Immunol., 39, 518-525.

39) Xie, Q. W., Whisnant, R. and Nathan, C. J. (1993) Promoter of the mouse gene encoding calcium-independent nitric oxide synthase confers inducibility by interferon $\gamma$ and bacterial lipopolysaccharide. Exp. Med., 177, 1779-1784.

40) Heinemeyer, T., Wingender, K., Reuter, L., Hermjakob, H., Kel, A. E., Kel, O. V., Ignatieva, E. V., Ananko, E. A., Podkolodnaya, O. A., Kolpakov, F. A., Podkolodny, N. L. and Kolchanov, N. A. (1998) Databases on transcriptional regulation: TRANSFAC, TRRD, and COMPEL. Nucleic Acids Res., 26, 364-370.

41) Akiyama, Y. (1995) TFSEARCH: Searching Transcription Factor Binding Sites. In TFSEARCH program, http://www.cbrc.jp/papia/.

42) Watters, J. J., Campbell, J. S., Cunningham, M. J., Krebs, E. G. and Dorsa, D. M. (1997) Rapid membrane effects of steroids in neuroblastoma cells: effects of estrogen on mitogen activated protein kinase signalling cascade and c-fos immediate early gene transcription. Endocrinology, 138, 4030-4033.

43) Mor, G., Sapi, E., Abrahams, V. M., Rutherford, T., Song, J., Hao, X. Y., Muzaffar, S. and Kohen, F.
(2003) Interaction of the estrogen receptors with the Fas ligand promoter in human monocytes. $J$. lmmunol., 170, 114-122.

44) Takeuchi, O. and Akira, S. (2002) Innate immunity — toll like receptor. In Immunological diseases state of arts, ver.2 (Imanishi, J., Yodoi, J., Minato, N. and Yamamoto, K., Eds.), Ishiyaku Publishers, Inc., Tokyo, Japan, pp. 156-160 (in Japanese).

45) Ninomiya-Tsuji, J. and Matsumoto, K. (2002) Signal transduction from interleukin-1. In Immunological diseases - state of arts, ver.2 (Imanishi, J., Yodoi, J., Minato, N. and Yamamoto, K., Eds.), Ishiyaku Publishers, Inc., Tokyo, Japan, pp. 101-105 (in Japanese).

46) Zhu, Y., Rice, C. D., Pang, Y., Pace, M. and Thomas, P. (2003) Cloning, expression, and characterization of a membrane progestin receptor and evidence it is an intermediary in meiotic maturation of fish oocytes. Proc. Natl. Acad. Sci. U.S.A., 100, 2231-2236.

47) Zhu, Y., Bond, J. and Thomas, P. (2003) Identification, classification, and partial characterization of genes in humans and other vertebrates homologous to a fish membrane progestin receptor. Proc. Natl. Acad. Sci. U.S.A., 100, 2237-2242.

48) You, H. J., Kim, J. Y. and Jeong, H. G. (2003) 17 $\beta$ estradiol increases inducible nitric oxide synthase expression in macrophages. Biochem. Biophys. Res. Commun., 303, 1129-1134.

49) Tomaszewska, A., Guevara, I., Wilczok, T. and Dembinska-Kiec, A. (2003) $17 \beta$-estradiol- and lipopolysaccharide-induced changes in nitric oxide, tumor necrosis factor- $\alpha$ and vascular endothelial growth factor release from RAW 264.7 macrophages. Gynecol. Obstet. Invest., 56, 152-159. 